\title{
Pengaruh Customer Relationship Management Terhadap Loyalitas Nasabah Bank "X" Di Bandung
}

\author{
Evan Jaelani \\ Program Studi Manajemen \\ Sekolah Tinggi Ilmu Ekonomi STAN IM, J1.Jakarta No.79 Bandung \\ Email : evanjae@stan-im.ac.id
}

\begin{abstract}
ABSTRAK
Penelitian ini bertujuan untuk menganalisis mengenai pengaruh Customer Relationship Management (CRM) yang terdiri dari sumberdaya manusia, proses dan teknologi terhadap loyalitas nasabah Bank "X" di Bandung. Teknik penarikan sampel yang digunakan adalah dengan metode accidental sampling. Data diperoleh dari 61 nasabah. Pengolahan data menggunakan analisis regresi berganda, hasil penelitian ini menunjukkan bahwa CRM yang terdiri dari sumberdaya manusia, proses, dan teknologi berpengaruh signifikan terhadap loyalitas nasabah. Sedangkan secara parsial hanya teknologi yang memiliki pengaruh tidak signifikan terhadap loyalitas nasabah, sedangkan sumberdaya manusia dan proses memiliki pengaruh signifikan terhadap loyalitas nasabah.
\end{abstract}

Kata Kunci : CRM, sumberdaya manusia, proses, teknologi, dan loyalitas.

\begin{abstract}
This study aims to analyze the influence of Customer Relationship Management (CRM) which consists of human resources, processes and technology to customer loyalty at Bank " $X$ " in Bandung. The sampling technique used is the accidental sampling method. Data obtained from 61 customers. Data processing using multiple regression analysis, the results of this study indicate that CRM consisting of human resources, processes, and technology has a significant effect on customer loyalty. While partially only technology has a non-significant effect on customer loyalty, while human resources and processes have a significant effect on customer loyalty.
\end{abstract}

Keywords: CRM, human resources, processes, technology, and loyalty.

\section{PENDAHULUAN}

Perkembangan perekonomian yang pesat di Indonesia menjadikan semakin eratnya hubungan antara masyarakat dengan dunia perbankan, sampai dengan hari ini sangat sedikit sekali masyarakat yang tidak menyimpan uangnya di Bank. Hal ini mengakibatkan banyak sekali bermunculan lembaga keuangan berupa Bank yang baru, sehingga persaingan dalam industri perbankan menjadi semakin ketat. Begitu juga dengan Bank " $\mathrm{X}$ " di Bandung yang mengalami penurunan nasabah terutama 
nasabah depositonya dalam beberapa terakhir ini, berikut adalah data deposan dari Bank "X":

Tabel 1. Jumlah Nasabah Deposito Bank " $X$ "

\begin{tabular}{|c|c|}
\hline TAHUN & $\begin{array}{c}\text { JUMLAH NASABAH } \\
\text { DEPOSITO }\end{array}$ \\
\hline 2012 & 352 \\
\hline 2013 & 389 \\
\hline 2014 & 361 \\
\hline 2015 & 344 \\
\hline 2016 & 341 \\
\hline 2017 & 332 \\
\hline 2018 & 327 \\
\hline 2019 & 318 \\
\hline & Sumber data : Bank "X" \\
\hline
\end{tabular}

Dapat dilihat dari tabel diatas bahwa Bank " $X$ " mengalami penurunan dalam hal nasabah terutama nasabah desposito, dimana nasabah deposito menjadi hal yang sangat penting bagi dunia perbankan karena mereka dapat memutarkan uang deposito tersebut untuk melakukan pinjaman kepada masyarakat dengan jangka waktu yang berbeda, sehingga mereka dapat keuntungan dari selisih bunga antara deposito dengan pinjaman.

Hal tersebut menunjukan bahwa loyalitas konsumen dari Bank " $\mathrm{X}$ " terutama nasabah deposito masih kurang, karena "loyalitas merupakan suatu pembelian ulang yang dilakukan oleh seorang pelanggan karena merupakan suatu komitmen pada suatu merek atau perusahaan” (Kotler dan Keller, 2016:18).

Sehingga diduga salah satu yang dapat membuat loyalitas pelanggan naik adalah dengan menerapkan Customer Relationship Management (CRM), karena "CRM merupakan suatu proses mendapatkan, mempertahankan, dan mengembangkan pelanggan yang menguntungkan dan memerlukan suatu fokus yang jelas terhadap atribut suatu jasa yang dapat menghasilkan nilai kepada pelanggan sehingga mendapatkan loyalitas" (Gramler and Brown, 1996:38). Oleh karena itu, alternatif yang baik adalah melakukan berbagai upaya untuk mempertahankan nasabah yang sudah ada, salah satunya adalah dengan usaha meningkatkan CRM untuk meningkatkan kesetiaan pelanggan. Melalui penerapan CRM, perusahaan diharapkan dapat membangun komunikasi dan hubungan yang baik dengan para 
pelanggannya sehingga mendorong terciptanya loyalitas nasabah. Menurut Chien dan Chen (2010), Customer Relationship Management (CRM) atau manajemen hubungan pelanggan terdiri dari tiga (3) komponen yaitu Sumber Daya Manusia, Proses, dan Teknologi. Hal ini senada dengan Sjoberg (2013) mengutarakan bahwa CRM mempunyai 3 dimensi yakni sumber daya manusia sebagai pelaksana CRM, Proses sebagai sistem CRM, dan Teknologi untuk mempercepat penerapan CRM.

Beberapa penelitian menyimpulkan hasil yang berbeda tentang pengaruh CRM perusahaan terhadap loyalitas pelanggan yang diukur oleh ketiga komponen tersebut, Ramani dan Kumar (2008) berpendapat manusia dan proses berpengaruh positif terhadap loyalitas pelanggan, sedangkan teknologi berpengaruh negatif terhadap loyalitas. Hal ini berbeda dengan penelitian Firdani, Rachmawati dan Prabowo (2015) yang berpendapat proses dan teknologi berpengaruh positif terhadap loyalitas pelanggan dan manusia berpengaruh negatif terhadap loyalitas pelanggan. Sedangkan penelitian Marwati, Irawati dan Saputra (2015) berpendapat komponen manusia, proses, dan teknologi berpengaruh positif terhadap loyalitas pelanggan.

Sehingga pada penelitian ini terdapat empat hipotesis, yaitu :

H1 : Sumberdaya Manusia dalam CRM berpengaruh positif terhadap Loyalitas

H2 : Proses dalam CRM berpengaruh positif terhadap Loyalitas

H3 : Teknologi dalam CRM berpengaruh postitif terhadap Loyalitas

H4 : CRM yang terdiri dari sumberdaya manusia, proses dan teknologi secara bersama-sama memiliki pengaruh signifikan terhadap Loyalitas

\section{METODE PENELITIAN}

Penelitian dalam artikel ini menggunakan metode penelitian kuantitatif, dengan metode deskriptif dan juga verifikatif. Metode deskriptif digunakan untuk mengetahui status sekelompok manusia, suatu objek, suatu set kondisi, suatu sistem pemikiran ataupun suatu kelas peristiwa pada masa sekarang, tujuannya adalah untuk membuat deskripsi, gambaran atau lukisan secara sistematis, faktual dan akurat mengenai fakta dan sifat hubungan antar fenomena yang diselidiki. Sedangkat metode verifikatif, menurut Mashuri (2008:45) yaitu memeriksa dengan benar tidaknya apabila dijelaskan untuk menguji suatu cara dengan atau tanpa 
perbaikan yang telah dilaksanakan dengan mengatasi masalah yang serupa dengan kehidupan.

Objek dalam penelitian ini adalah Customer Relationship Management (CRM) yang terdiri dari sumberdaya manusia, proses dan teknologi, serta loyalitas nasabah. Sedangkan lokasi yang dijadikan tempat penelitian adalah Bank " $X$ " yang terdapat di Bandung. Populasi penelitian ini adalah rata-rata deposan selama 8 (delapan) tahun terakhir yaitu 346, sedangkan yang dijadikan sampel dalam penelitian ini adalah sebanyak 61 orang, dengan teknik pengambilan sampel yang digunakan adalah dengan menggunakan accidental sampling. Teknik analisis yang digunakan adalah dengan menggunakan regresi linier berganda. Instrumen pengukuran yang digunakan dalam penelitian ini diadaptasi dari Sjoberg (2013) untuk variabel CRM yang terdiri dari sumberdaya manusia, proses dan teknologi, serta Taylor and Baker (1994) untuk variabel Loyalitas.

\section{HASIL DAN PEMBAHASAN}

\subsection{Statistik Deskriptif}

Berikut adalah resume tanggapan responden terhadap variabel Sumberdaya Manusia dalam CRM :

Tabel 2. Resume Total Skor Sumberdaya Manusia dalam CRM

\begin{tabular}{|c|c|c|}
\hline Pernyataan & $\begin{array}{c}\text { Skor } \\
\text { rata-rata }\end{array}$ & Kriteria \\
\hline 1 & 227 & Tinggi \\
\hline 2 & 226 & Tinggi \\
\hline 3 & 219 & Tinggi \\
\hline 4 & 215 & Tinggi \\
\hline RATA-RATA & $\mathbf{2 2 2}$ & Tinggi \\
\hline
\end{tabular}

Sumber : Hasil Pengolahan Data

Untuk variabel sumberdaya manusia dalam CRM mencapai skor 222, yang dapat dikategorikan tinggi, artinya sumberdaya manusia dalam CRM pada Bank " $X$ " di Bandung sudah baik. Namun sumberdaya manusia dalam CRM tersebut harus tetap ditingkatkan terutama pada pernyataan yang masih mendapat skor terendah. Berikut resume tanggapan responden untuk variabel bauran proses dalam CRM : 
Tabel 3. Resume Total Skor Proses dalam CRM

\begin{tabular}{|c|c|c|}
\hline Pernyataan & $\begin{array}{c}\text { Skor } \\
\text { rata-rata }\end{array}$ & Kriteria \\
\hline 1 & 222 & Tinggi \\
\hline 2 & 218 & Tinggi \\
\hline 3 & 216 & Tinggi \\
\hline RATA - RATA & $\mathbf{2 1 9}$ & Tinggi \\
\hline
\end{tabular}

Sumber : Hasil Pengolahan Data

Untuk variabel proses dalam CRM mencapai skor 219, yang dapat dikategorikan tinggi, artinya proses dalam CRM pada Bank " $X$ " di Bandung sudah baik namun proses dalam CRM tersebut masih tetap perlu ditingkatkan terutama pada pernyataan yang mendapatkan skor terendah dari responden. Berikut adalah resume tanggapan responden untuk variabel teknologi dalam CRM :

Tabel 4. Resume Total Skor Teknologi dalam CRM

\begin{tabular}{|c|c|c|}
\hline Pernyataan & $\begin{array}{c}\text { Skor } \\
\text { rata-rata }\end{array}$ & Kriteria \\
\hline 1 & 219 & Tinggi \\
\hline 2 & 221 & Tinggi \\
\hline 3 & 230 & Tinggi \\
\hline RATA - RATA & $\mathbf{2 2 3}$ & Tinggi \\
\hline
\end{tabular}

Sumber : Hasil Pengolahan Data

Untuk variabel teknologi dalam CRM mencapai skor 223, yang dapat dikategorikan tinggi, artinya teknologi dalam CRM pada Bank " $\mathrm{X}$ " di Bandung sudah baik. Namun agar teknologi dalam CRM lebih baik lagi, tetap harus ditingkatkan terutama pada pernyataan yang mendapatkan nilai terendah dari responden.

Dari ketiga tabel resume diatas, secara keseluruh Customer Relationship Management (CRM) yang terdiri dari sumberdaya manusia, proses dan teknologi berada pada kategori tinggi, artinya responden yang ada dalam penelitian ini adalah nasabah deposito Bank "X" di Bandung, menyatakan penerapan CRM di Bank "X" sudah baik. Sedangkan untuk loyalitas nasabah mendapatkan skor sebagai berikut : 
Tabel 5. Resume Total Skor Loyalitas Nasabah dalam CRM

\begin{tabular}{|c|c|c|}
\hline Pernyataan & $\begin{array}{c}\text { Skor } \\
\text { rata-rata }\end{array}$ & Kriteria \\
\hline 1 & 222 & Tinggi \\
\hline 2 & 226 & Tinggi \\
\hline 3 & 226 & Tinggi \\
\hline 4 & 240 & Tinggi \\
\hline RATA - RATA & $\mathbf{2 2 9}$ & Tinggi \\
\hline
\end{tabular}

Sumber : Hasil Pengolahan Data

Untuk variabel loyalitas nasabah mencapai skor 229, yang dapat dikategorikan tinggi, artinya loyalitas nasabah pada Bank " $\mathrm{X}$ " di Bandung sudah baik. Namun agar loyalitas nasabah lebih baik lagi, tetap harus ditingkatkan terutama pada pernyataan yang mendapatkan nilai terendah dari responden.

\subsection{KORELASI ANTAR VARIABEL}

Berikut adalah hasil dari korelasi antar variabel dalam penelitian ini :

Tabel 6. Koefisien Korelasi

\begin{tabular}{|c|l|r|}
\hline \multicolumn{2}{|c|}{} & \multicolumn{1}{|c|}{$\begin{array}{c}\text { Loyal- } \\
\text { itas }\end{array}$} \\
\hline \multirow{2}{*}{ SDM } & $\begin{array}{l}\text { Pearson Corre- } \\
\text { lation }\end{array}$ & $.953^{* *}$ \\
\cline { 2 - 3 } & Sig. (2-tailed) & .000 \\
\cline { 2 - 3 } & $\mathrm{N}$ & 61 \\
\hline \multirow{2}{*}{ Proses } & $\begin{array}{l}\text { Pearson Corre- } \\
\text { lation }\end{array}$ & $.953^{* *}$ \\
\cline { 2 - 3 } & Sig. (2-tailed) & .000 \\
\cline { 2 - 3 } Teknolo & N & 61 \\
\hline \multirow{2}{*}{ gi } & $\begin{array}{l}\text { Pearson Corre- } \\
\text { lation }\end{array}$ & $.940^{* *}$ \\
\cline { 2 - 3 } & Sig. (2-tailed) & .000 \\
\cline { 2 - 3 } & N & 61 \\
\hline
\end{tabular}

Sumber : Hasil Pengolahan Data

Berdasarkan hasil perhitungan pada tabel 6 tersebut diatas, dapat disimpulkan bahwa besarnya koefisien korelasi sumberdaya manusia dalam CRM dan loyalitas nasabah adalah 0,953 yang berarti keduanya memiliki hubungan yang positif dan nilai signifikansi yang lebih kecil dari 0,05 yaitu sebesar 0,000 menunjukan bahwa 
hubungan keduanya adalah signifikan. Untuk besaran koefisien korelasi proses dalam CRM dan loyalitas nasabah adalah 0,953 yang berarti keduanya memiliki hubungan yang positif serta nilai signifikansi yang lebih kecil dari 0,05, yaitu sebesar 0,000, yang berarti keduanya memiliki hubungan yang signifikan. Serta untuk besaran koefisien korelasi teknologi dalam CRM dan loyalitas nasabah adalah 0,940 yang berarti keduanya memiliki hubungan yang positif serta nilai signifikansi yang lebih kecil dari 0,05, yaitu sebesar 0,000, yang berarti keduanya memiliki hubungan yang signifikan.

\subsection{PENGUJIAN HIPOTESIS}

Pada pengujian hipotesis ini, yang pertama kali dilakukan adalah uji F. Dengan hipotesis statistik yang diajukan adalah sebagai berikut :

$$
\begin{aligned}
\mathrm{H}_{0}: \mathrm{b}_{1}, \mathrm{~b}_{2}, \mathrm{~b}_{3}= & \text { Secara simultan CRM yang terdiri dari sumberdaya } \\
0, & \text { manusia, proses dan tekonologi memiliki pengaruh tidak } \\
& \text { signifikan terhadap loyalitas nasabah. } \\
\mathrm{H}_{\mathrm{a}}: \mathrm{b}_{1}, \mathrm{~b}_{2}, \mathrm{~b}_{3} \neq & \text { Secara simultan CRM yang terdiri dari sumberdaya } \\
0, \quad & \text { manusia, proses dan tekonologi memiliki pengaruh } \\
& \text { signifikan terhadap loyalitas nasabah. }
\end{aligned}
$$

Tabel 7. Uji F

\begin{tabular}{|l|l|r|r|r|r|r|}
\hline \multicolumn{2}{|l|}{} & \multicolumn{1}{|c|}{$\begin{array}{l}\text { Sum of } \\
\text { Squares }\end{array}$} & \multicolumn{1}{c|}{ df } & \multicolumn{1}{c|}{$\begin{array}{c}\text { Sean } \\
\text { Square }\end{array}$} & \multicolumn{1}{c|}{ F } & Sig. \\
\hline \multirow{2}{*}{1} & $\begin{array}{l}\text { Regres- } \\
\text { sion }\end{array}$ & 1697.163 & 3 & 565.721 & 237.41 & $.000^{\mathrm{b}}$ \\
\cline { 2 - 7 } & Residual & 135.821 & 57 & 2.383 & & \\
\cline { 2 - 7 } & Total & 1832.984 & 60 & & & \\
\hline
\end{tabular}

Sumber : Hasil Pengolahan Data

Berdasarkan tabel 7 didapat hasil uji $\mathrm{F}$ hitung sebesar 237.417 dengan tingkat probalitas pada level 0,000 sig (signifikansi). Syarat uji yang digunakan adalah apabila pada taraf signifikansi 5\% $(\alpha=0,05)$. Nilai probabilitas (probabilitas value) koefisien regresi di bawah dari pada 0,05 hal itu menunjukan bahwa CRM yang terdiri dari Sumberdaya Manusia, Proses dan Teknologi secara bersama-sama memiliki pengaruh signifikan terhadap Loyalitas Nasabah. Berdasarkan analisis 
secara keseluruhan yang telah dilakukan maka diperoleh bahwa secara bersamasama CRM yang terdiri dari sumberdaya manusia, proses, dan teknologi memiliki pengaruh positif signifikan terhadap loyalitas nasabah deposito di Bank "X", hasil ini sejalan dengan penelitian yang dilakukan oleh Firdani, Rachmawati dan Prabowo (2015). Sedangkan hasil pengujian uji t pada penelitian ini adalah sebagai berikut :

Tabel 8. Uji t

\begin{tabular}{|c|c|c|c|c|c|c|}
\hline \multirow{2}{*}{\multicolumn{2}{|c|}{ Model }} & \multicolumn{2}{|c|}{$\begin{array}{c}\text { Unstandardized } \\
\text { Coefficients }\end{array}$} & \multirow{2}{*}{$\begin{array}{c}\text { Standardized } \\
\text { Coefficients } \\
\text { Beta } \\
\end{array}$} & \multirow[b]{2}{*}{$\mathrm{t}$} & \multirow{3}{*}{$\begin{array}{l}\text { Sig. } \\
.317\end{array}$} \\
\hline & & B & $\begin{array}{l}\text { Std. } \\
\text { Error }\end{array}$ & & & \\
\hline \multirow[t]{4}{*}{1} & (Constant) & .587 & .582 & & 1.009 & \\
\hline & SDM & .407 & .172 & .392 & 2.365 & .021 \\
\hline & PROSES & .598 & .195 & .444 & 3.067 & .003 \\
\hline & TEKNOLOGI & .186 & .201 & .138 & .929 & .357 \\
\hline
\end{tabular}

Sumber : Hasil Pengolahan Data

Berdasarkan hasil perhitungan diatas seperti yang terlihat pada tabel 8 diperoleh nilai signifikan sebagai berikut:

a. Sumberdaya Manusia

$\mathrm{H}_{0}: \mathrm{b}_{1}=0$ : Sumberdaya Manusia dalam CRM berpengaruh tidak signifikan terhadap Loyalitas Nasabah

$\mathrm{H}_{1}: \mathrm{b}_{1}>0$ : Sumber Daya Manusia dalam CRM berpengaruh positif dan signifikan terhadap Loyalitas Nasabah

Koefisien regresi untuk variabel Sumberdaya Manusia dalam CRM adalah sebesar 0,407 dan signifikan pada level 0,021. Karena 0,021 $<0,05$ maka $\mathrm{H}_{0}$ ditolak artinya bahwa Sumberdaya Manusia dalam CRM berpengaruh positif dan signifikan terhadap Loyalitas Nasabah. Dari hasil penelitian yang telah dilakukan dan dijelaskan diatas, maka dapat disimpulkan bahwa untuk hipotesis pertama membuktikan bahwa Sumberdaya Manusia dalam CRM berpengaruh positif signifikan terhadap Loyalitas Pelanggan. Dengan demikian semakin tinggi sumberdaya manusia maka loyalitas nasabah juga akan semakin tinggi. Artinya bahwa sumber daya manusia semakin baik maka nasabah akan semakin 
loyal. Hal ini sejalan dengan penelitian yang dilakukan oleh Mawarti, Irawati, dan Saputra (2015).

b. Proses

$\mathrm{H}_{0}: \mathrm{b}_{2}=0$ : Proses dalam CRM berpengaruh tidak signifikan terhadap Loyalitas Pelanggan

$\mathrm{H}_{2}: \mathrm{b}_{2}>0$ : Proses dalam CRM berpengaruh positif dan signifikan terhadap Loyalitas Pelanggan

Koefisien regresi untuk variabel Proses dalam CRM adalah sebesar 0,598 dan signifikan pada level 0,003. Karena $0,003<0,05$ maka $\mathrm{H}_{0}$ ditolak artinya bahwa Proses dalam CRM berpengaruh positif dan signifikan terhadap Loyalitas Nasabah. Sedangkan untuk hipotesis kedua menunjukan bahwa Proses dalam CRM berpengaruh positif signifikan terhadap Loyalitas Nasabah. Dengan demikian semakin tinggi proses maka loyalitas pelanggan juga akan semakin tinggi. Artinya bahwa semakin baik proses yang ada maka nasabah akan semakin loyal. Hal ini sejalan dengan penelitian yang di lakukan oleh Sjoberg (2013).

c. Teknologi

$\mathrm{H}_{0}: \mathrm{b}_{3}=0$ : Teknologi dalam CRM berpengaruh tidak signifikan terhadap Loyalitas Pelanggan

$\mathrm{H}_{3}: \mathrm{b}_{3}>0$ : Teknologi dalam CRM berpengaruh positif dan signifikan terhadap Loyalitas Pelanggan

Koefisien regresi untuk variabel Teknologi dalam CRM adalah sebesar 0,186 dan tidak signifikan pada level 0,357. Karena 0,357>0,05 maka $\mathrm{H}_{0}$ tidak ditolak artinya bahwa Teknologi dalam CRM berpengaruh tidak signifikan terhadap Loyalitas Nasabah. Sedangkan untuk hipotesis ketiga menunjukan bahwa teknologi dalam CRM berpengaruh tidak signifikan terhadap loyalitas pelanggan. Dengan demikian maka semakin tinggi teknologi dalam CRM tidak akan meningkatkan loyalitas nasabahnya. Ini terjadi kemungkinan besar karena nasabah deposito di Bank "X" tidak terlalu mementingkan masalah teknologi dalam CRM, mereka hanya peduli dengan sumberdaya manusia dan proses, yang artinya paling penting bagi mereka adalah pelayanan yang dilakukan oleh Bank 
"X" maka mereka sudah merasa tercukupi, dan juga ada kemungkinan lain yaitu sebagian besar nasabah deposito terutama yang menjadi responden tidak terlalu mengerti dengan teknologi, sehingga mereka mengacuhkan masalah teknologi dalam CRM. Hal ini sejalan dengan penelitian yang di lakukan oleh Firdani, Rachmawati dan Prabowo (2015).

Tabel 9. Koefisien Determinasi

\begin{tabular}{|c|c|c|}
\hline Model & R & R Square \\
\hline 1 & $.962^{\mathrm{a}}$ & .926 \\
\hline
\end{tabular}

Sumber : Hasil Pengolahan Data

Hasil analisis koefisien determinasi $\left(\mathrm{R}^{2}\right)$ menunjukkan bahwa kontribusi variabel sumberdaya manusia dalam CRM, proses dalam CRM dan teknologi dalam CRM terhadap perubahan yang terjadi pada loyalitas nasabah adalah sebesar $92,6 \%$. Adapun sisanya sebesar $7,4 \%$ dijelaskan oleh variabel lain yang tidak diteliti dalam penelitian ini seperti inovasi produk (Yelin dan Nguyen, 2011).

\section{SIMPULAN}

Kesimpulan yang dapat diambil dari penelitian ini adalah bahwa CRM yang terdiri dari sumberdaya manusia, proses dan teknologi secara bersama-sama berpengaruh signifikan terhadap loyalitas nasabah Bank " $X$ " di Bandung. Sedangkan secara parsial sumberdaya manusia dalam CRM berpengaruh positif dan signifikan terhadap loyalitas nasabah Bank "X" di Bandung, berikutnya secara parsial proses dalam CRM berpengaruh positif dan signifikan terhadap loyalitas nasabah Bank "X" di Bandung, sedangkan teknologi dalam CRM berpengaruh positif namun tidak signifikan terhadap loyalitas nasabah Bank " $X$ " di Bandung. Sehingga saran yang dapat diberikan adalah dengan meningkatkan sumberdaya manusia dalam CRM terutama pada poin "selalu ramah dalam melayani nasabahnya" karena itu mendapat skor paling rendah dari SDM dalam CRM, dengan cara memberikan pelatihan mengenai pelayanan terhadap nasabahnya yang ditekankan pada keramahan. Berikutnya adalah dengan meningkatkan proses dalam CRM terutama 
pada poin "sering memberikan promo bunga lebih dan pemberian cashback" karena itu mendapat skor paling rendah dari proses dalam CRM, dengan cara memberikan promo-promo tertentu untuk nasabah dalam rentang waktu yang sudah ditentukan, terutama pada waktu-waktu yang mengalami penurunan simpanan nasabah. Hal ini dikarenakan kedua variabel tersebut memiliki pengaruh yang positif dan signifikan terhadap loyalitas nasabah.

\section{DAFTAR PUSTAKA}

Chien, S-H. and Chen, J-J. (2010). Supplier Involvement and Customer Involvement Effect on New Product Development Success in the Financial Service Industry. Service Industries Journal, Vol. 30, Issue. 2, pp. 185-201.

Eric Fang \& Robert W. Palmatier \& Kenneth R. Evans., (2007). Influence of customer participation on creating and sharing of new product value. Academy of Marketing Science 2007.

Firdani, Firman., Indira Rachmawati, dan Fajar Prabowo (2015). Pengaruh Customer Relationship Manajemen Terhadap Loyalitas Pelanggan Paket Data Telkomsel (Studi Kasus di Kota Bandung). Telkom University.

Gordon, Ian. (2002). Best Practices: Customer Relationship Management. Ivey Business Journal.

Gremler, D. D and Brown S. W, (1996). Service Loyalty : Its Nature, Importance, and Implication.

Kotler, Philip and Kevin Lane Keller, (2012). Marketing Management, $15^{\text {th }}$ Edition, Pearson Education, Inc.

Mashuri (2008). Penelitian Verifikatif. Edisi Pertama. Yogyakarta. Andi.

Mawarti, Jamilah, Nalarati., Dwi Irawati., dan Murry Hermawan Saputra (2015). Pengaruh Customer Relationship Management Terhadap Loyalitas Pelanggan PT. Kereta Api Indonesia. Universitas Muhammadiyah Purworejo.

Payne, A. and Frow, P. (2005). A Strategic Framework for Customer Relationship Management. Journal of Marketing, Vol. 69, Issue. 4, pp. 167-176.

Ramani, G. and Kumar, V. (2008), Interaction Orientation and Firm Performance. Journal of Marketing, Vol. 72, Issue. 1, pp. 27-45.

Reinartz, W., Krafft, M. and Hoyer, W. (2004). The Customer Relationship Management Process: Its Measurement and Impact on Performance. Journal of Marketing Research, Vol. 41, Issue. 3, pp. 293-305.

Sin, L., Tse, A. and Yim, L. (2005). CRM : Conceptualization and Scale Development. European Journal of Marketing, Vol. 39, Issue. 11/12, pp. 1264-90.

Sjoberg, Amelie. (2013). Product innovation and the effect of CRM-a quantitative study. Master thesis, Business administration, Linnaeus University. 
Taylor, S. A., and T. L. Baker., (1994). An Assesment of the Relationship between Service Quality and Customer Loyalty. Journal of Retailing.

Yelin, and Nguyen. (2011). Impact of customer relationship management on product innovation process. Master thesis. Business administration, Lulea Tekniska Universitet. 